DOE/OR/21555-.T5

\title{
THE PUBLIC RESPONSE TO
}

\section{MONITORED RETRIEVABLE STORAGE}

DOE/OR/21555--T5

DE92 011927

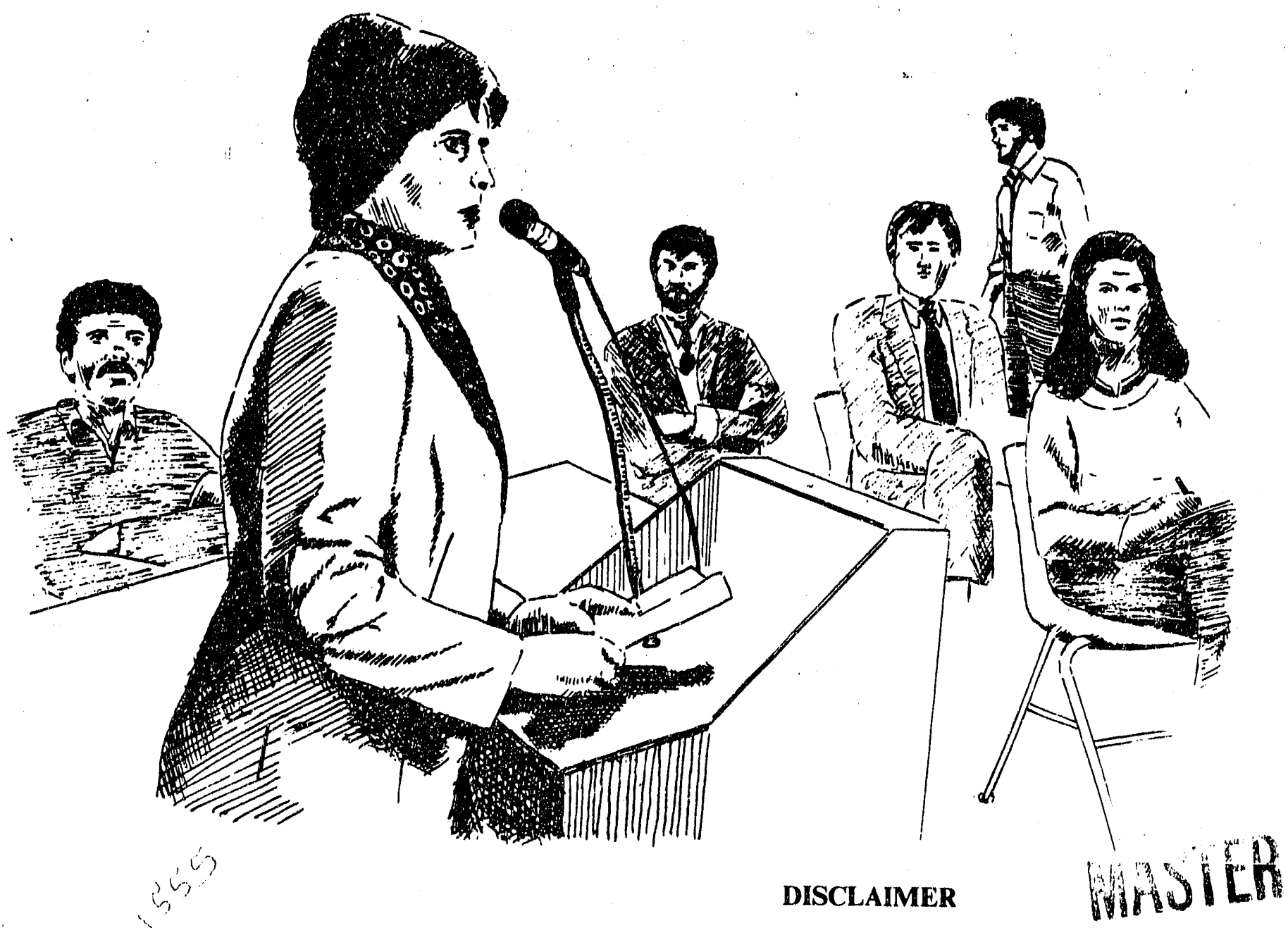

This report was prepared as an account of work sponsored by an agency of the United States Government. Neither the United States Government nor any agency thereof, nor any of their employees, makes any warranty, express or implied, or assumes any legal liability or responsibility for the accuracy, completenesı, or usefulness of any information, apparatus, product, or process disclosed, or represents that its use would not infringe privately ownerl rights. Reference herein to any specific commercial product, process, or service by trade name, trademark, manufacturer, or otherwise does not necessarily constitute or imply its endorsement, recommendation, or favoring by the United States Government or any agency thereof. The views and opinions of authors expressed herein do not necessarily state or reflect those of the United States Government or any agency thereof. 


\section{THE PUBLIC RESPONSE}

TO MRS:

\section{AN INTERIM REPORT}

\section{Prepared For \\ Safe Growth Cabinet Council}

by

The Safe Growth Staff

Tennessee Departinent of Health and Environment

October 22, 1985 


\begin{abstract}
A Report on the Public's Response
to the Safe Growth Cabinet Council

Regarding

The Department of Energy's Proposal

to site a

Monitored Retrievable Storage Facility

in Tennessee
\end{abstract}

\author{
Prepared By The \\ Safe Growth Staff \\ of the \\ Safe Growth Cabinet Council \\ October 1985
}


A Note from the Staff

Introduction

Executive Summary 7

Category I: Letters Submitted

General Summary

Summary Details

15

Letters Expressing Opposition 20

Letters Expressing Support

Letters Providing Information

Category II: Petitions Submitted

General Summary

Summary Details 36

Category III: Questionnaires Submitted . 37

$\begin{array}{ll}\text { About the Questionnaire } & 38\end{array}$

General Summary $\quad 40$

Summary Details 41

Example Responses $\quad 47$

Category IV: Public Hearings 60

About the Hearings 61

Public Hearings Summary $\quad 62$

Chattanooga 64

$\begin{array}{ll}\text { Knoxville } & 66\end{array}$

Lebanon $\quad 69$

$\begin{array}{ll}\text { Memphis } & 71\end{array}$ 
Page

Category V: Media Coverage $\quad 73$

Category VI: Resolutions 76

Copies of Resolutions 
A Note from the Staff

As you may imagine, considerable effort has gone into this report. Much of the effort has been on your part. The 128 letters received, four petitions containing 498 names, 68 completed questionnaires, numerous newspaper articles, and the 300 people who attended four public hearings held across the state all represent a lot of time and thought given to some very important issues relating to the Department of Energy's proposal to site a monitored retrievable storage facility in Tennessee.

Reading and re-reading your ideas and responses, listening to tapes of the hearings, and compiling the results have been lengthy processes. Since this is a summary, a categorization of the responses is necessary to put the many ideas, beliefs, and opinions expressed into perspective. We hope that the result is in a format that is both understandable and meaningful. Although it is impossible to include every comment, we have included those most frequently given, as well as some that were unique or meriting consideration even if not mentioned often. As might be expected, we do not necessarily agree with all the comments, but then the purpose of this report is to insure as many Tennesseans' participation in the consideration of DOE's proposal as is possible. The purpose of this summary is to report back to you the results of vour efforts.

Ben L. Smith

Dr. Ruth Neff

Gay I. Hashbarger

Rita Currey

Ann Shapiro 
Introduction

What the public has responded to: The Department of Energy proposal on MRS

The National Waste Policy Act of 1982 directed the U.S. Department of Energy (DOE) to ". . . complete a detailed study of the need for and feasibility of ... construction of one or more monitored retrievable storage facilities for high-level radioactive waste and spent nuclear fuel."

A Preliminary Need and Feasibility Analysis (DOE/R W-0022) was issued by DOE in April 1985. It was accompanied by a document entitled, "Screening and Identification of Sites for a Proposed Monitored Retreivable Storage Facility" (DOE/RW-0023), which identified three potential sites in Tennessee for construction of the proposed facility. The DOE preferred site is the Clinch River Breeder Reactor site southwest of the city of Oak Ridge in Roane County. Alternate sites include a tract of land on the Oak Ridge Reservation and the Hartsville Nuclear Plant site in Trousdale County.

In January 1986, DOE plans to submit a definitive proposal, a final Need and Feasibility Report and Environrnental Assessment and a Program Plan to Congress. The documents will be accompanied by an independent evaluation of the proposal by the Nuclear Regulatory Commission and the Environmental Protection Agency. On the basis of these submissions and with the input from the State, Congress will decide whether to authorize an MRS as a part of the national waste management system, 
Including the publlc in the analysis process:

The State has undertaken an extensive process to study the Monitored Retrievable Storage proposal. It is the responsibility of the Safe Growth Cabinet Council to gather all relevant data regarding MRS, to conduct an independent technical review, and to report that information to the Governor. Five major issues are being addressed by the Council. These include: (1) Is MRS safe and could it be harmful to the health of the public and/or the environment; (2) What are the added risks associated with the transportation of nuclear waste to an MRS in Tennessee; (3) What are the economic costs and/or benefits of an MRS facility in Tennessee; (4) What should the State's role be; and (5) What are the attitudes of Tennessee's citizens and communities about MRS (in Hartsville, Oak Ridge, and all across the state). It is this last concern that has caused the Safe Growth Cabinet Council to undertake numerous activities to insure that we obtain accurate representations of our citizen's attitudes. 
Community Attitudes

The DOE proposal directly affects two Tennessee communities. The DOE preferred site is the Clinch River Breeder Reactor site southwest of the city of Oak Ridge in Roane County. An alternate site is located on a tract of land located on the Oak Ridge Reservation. Another alternate site is the Hartsville Nuclear Plant site in Trousdale County. These two communities have been granted funds by the federal government to conduct their own evaluations of the MRS proposal.

The Oak Ridge-Roane County area is represented by the "Clinch River MRS Task Force." It is comprised of environmental, socioeconomic, and transportation study groups with aid from an executive committee. The Hartsville area is represented by a five county "Research, Evaluation, Analysis, and Liasion Group." The five counties represented include Trousdale, Smith, Wilson, Sumner and Macon. Both of these groups will independently analyze the proposal and submit complete reports to the Safe Growth Cabinet Council during November and December of this year. 


\section{Public Opinions Contained in this Report}

As noted earlier, the purpose of this summary is to report back to the 756 individuals who have communicated their attitudes and opinions concerning the MRS proposal directly to Governor Alexander, the Safe Growth Cabinet Council or other state agencies. This report will also be provided to the Governor to assist him in understanding how Tennesseans feel about having a monitored retrievable storage facility in their state.

The responses submitted have come in a variety of forms and will be grouped accordingly to aid in the organization and presentation of those views. The first category is a summary of the 128 letters that have been individually submitted. The second category will discuss four petition-type letters comprising 498 names of individuals expressing their oppositicn to the DOE proposal. The third category includes summaries of the 68 questionnaires that have been returned to the Safe Growth Office. These questionnaires were distributed at the four public hearings conducted by the Safe Growth Cabinet Council. These questionnaires were prepared by the Safe Growth Staff to create a medium to encourage citizen response. The hearings will be summarized in the fourth category. Both the oral testimonies and the written comments submitted by individuals and groups will be discussed. Fifth, a brief discussion of the numerous articles published by the media, that we have knowledge of, will be noted. Finally, an acknowledgment of resolutions that have been passed by municipalities and groups will be noted. This report will reflect information that has been gathered between May and October 22, 1985. 
A final report on community attitudes will be prepared for Governor Alexander. Public opinions expressed between October 22 and December 20, 1985, will be summarized. The final report will also include a summary of the four public meetings to be held in the first two weeks in December, additional letters, petitions and questionnaires received, and the results of a toll-free telephone service provided by the state to allow individuals to call in and voice their opinions. 
EXECUTIVE SUMMARY

$-7-$ 


\section{Executive Summary}

A total of 756 individuals have expressed their opinions to Governor Alexander and/or the Safe Growth Cabinet Council concerning the Department of Energy's proposal to locate a monitored retrievable storage facility in Tennessee. Of the total, 677 individuals oppose a MRS facility in Tennessee, 38 individuals support the DOE proposal, and 41 individuals were either neutral, provided some information to be considered or posed questions.

The table below indicates the various means by which these opinions have been received and recorded. The numbers in parentheses indicate persons who have expressed their opinions in one of the other methods available. The purpose is to insure that our totals represent an accurate number of individuals without duplication distorting the figures. 
Public Response on MRS

\begin{tabular}{lccc} 
& Oppore & Support & Other/Neutral \\
\cline { 2 - 3 } & 108 & 10 & 10 \\
Letters & 498 & 0 & 0 \\
Petition Signatures & $33(+2)$ & $22(+4)$ & 23 \\
Safe Growth Questionnaires & 4 & $1(+2)$ & 2 \\
Chattanooga Hearing & $9(+1)$ & $5(+3)$ & 4 \\
Knoxville Hearing & $15(+10)$ & 0 & 0 \\
Lebanon Hearing & 10 & 0 & 2 \\
Memphis Hearing & 677 individuals & 38 individuals & 41 individuals \\
& &
\end{tabular}


The letters, questionnaires and public hearings provided an opportunity for individuals to express why they are opposed to or in support of the DOE proposal. The following is a summary of the most frequently cited reasons:

Most Frequently Cited Reasons for Opposition

Number of Individuals

Transportation Risks and Costs Citing This Reason

Pollution of Environment 61

"Need" Unproven - Utilize Present Storage Permanent Repository

Public Health and Safety 43

MRS Might Become Permanent 40

DOE's "Poor Track Record" 32

Adverse Socioeconomic Impact 30

Improper Site Selection 12

Negative Impact on Tourism 11 
Most Frequently Cited Reasons for Support

Transportation Can Occur Safely

MRS Can Be Operated Safely for the Environment and Public Health

Provide Employment

Industrial Expansion and Spin-Off

Retention of Technical Expertise in the Oak Ridge Area

MRS is Optimal Solution to the Nation's Nuclear

Waste Management Needs

Increased Tax Base

MRS is Important to the Continuance of Nuclear Energy

Enhance Tourism

Improve Roads
Number of Individuals

Citing This Reason

30

22

14

9

6

6

5

3

2

2 
Summary of Geographic Distribution of Opposition/Support

The 677 individuals expressing opposition to the DOE proposal extend across the state from Memphis to Kingsport. Middle Tennessee citizens volced their opposition most frequently, followed by East Tennesseans and then West Tennesseans.

The 38 individuals who have expressed their support of the location of an MRS facility in Tennessee have all supported the Oak Ridge sites and all but one are from East Tennessee. Nineteen reside in Oak Ridge, twelve in Knoxville, one each in Chattanooga, Kingston, and Mt. Pleasant, Tennessee. Four did not provide an address.

\section{Conclusion}

The majority of individuals who have expressed their opinions are opposed to the location of an MRS facility in Tennessee. 
Category I

Letters to Governor Alexander and other State Officials and Agencies

$-13-$ 


\section{General Summary}

Many citizens across the state have taken time to write a letter expressing their views and opinions on an MRS facility being located in Tennessee. Governor Alexander has received 117 letters from such interested parties. Commissioner Jim Word and the Safe Growth Cabinet Council received an additional 11 letters for a total of 128 letters received. The majority of the letters received have expressed opposition to the DOE proposal. Of the 128 letters received, 108 people expressed opposition to the location of an MRS facility in Tennessee. Ten individuals wrote to express their support of locating an MRS facility in this state. Another ten people expressed the need for an objective and responsible analysis of the proposal based on factual data or they provided information and articles concerning the MRS proposal that they felt might assist the Governor in the decision making process.

The letters came from a variety of individuals and locations. The majority of the letters, 84, came from residents of Middle Tennessee while 35 came from East Tennessee, five from West Tennessee, and four from out of state. 
I. Individual attitudes

No. of Individuals

$\begin{array}{ll}\text { Opposed } & 108\end{array}$

$\begin{array}{ll}\text { Support } & 10\end{array}$

$\begin{array}{ll}\text { Neutral/Other } & 10\end{array}$

II. Reasons/Opinions for Opposition

Pollution of environment $\quad 29$

$\begin{array}{ll}\text { Public health and safety } & 20\end{array}$

Transportation risks and costs $\quad 25$

Maintain waste on site, then ship to permanent repository 19

MRS might become permanent $\quad 22$

$\begin{array}{ll}\text { Adverse socioeconomic impact } & 16\end{array}$

Opposed to all nuclear power aspects 9

Improper site selection by DOE $\quad 6$

Opposed - no reason given 33

III. Reasons/Opinions for Support

Provide employment 3

Industrial expansion and spin-off industries 3

Retention of technical expertise in Oak Ridge 2 
Increased tax base

Can be operated safely for the environment and public $\quad 6$

Transportation is safe $\quad 2$

Enhance tourism 1

Imperative to continuance of nuclear energy 1

IV. Neutral Opinions or Providing Information

Analysis should be objective and thorough 3

Information provided regarding legislation 5

Wompensation to host community recommended 2

V. Geographic Distribution of Opposition/Support/Neutral-Other

Opposition

No. of Individuals

Bluegrass

1

Celina

1

Chattanooga 1

Cleveland 1

Cosby

Dickson

Dixon Springs 1

Dyersburg 1

Erwin 
Opposition Con't.

No. of Individuals

Fosterville

Franklin

Gatlinburg

Gordonsville

Hartsville

Hendersonville

Hilham

Hohenwald

Humboldt

2

Jackson

Joel ton

1

Knoxville

LaFayette

8

Lebanon 2

Lenoir City

Lewisburg

1

Lobelville

1

Madison

Maryville

Memphis

1

Morristown

Murfreesboro

Nashville

Norris

Nunnelly

Oak Ridge 
Opposition Con't.

No. of Individuals

Old Hickory

Oliver Springs

Pegram

Savannah

Sewanee

Signal Mountain

Smithville

Summertown

Tullahoma

Washington, DC

White Bluff

Whitleyville

Support

Knoxville

Oak Ridge

Neutral/Other

Chattanooga

Knoxville

Maine State

Nashville

Nevada State

Oak Ridge

Wrshing ton State 
VI. Summary of Geographic Distribution of Letters Submitted

West

Middle

East

Out of State

Opposition

West

Middle

East

Out nf State
5 letters

84 letters

35 letters

4 letters

No. of Individuals

Support

West

0

Middle

0

East

10

Neutral

West

0

Middle

2

East

5

Out of State

3

$-19-$ 
Letters Expressing Opposition to the Location of an URS Facillty in Tennessee

A total of 108 letters were recelved volcing opposition to the DOE proposal. They expressed a diverse range of views concerning health and safety, socloeconomic. impacts, transportation, the Issue of temporary versus permanent, alternative solutions, the desirability of nuclear energy, the site selection process, and simple opposition. A more detalled discussion of these letters follows.

The most often stated reason for opposition to an MRS facility being located in Tennessee Involved concern for public health and safety and fear of pollution to the environment. Concern that the environment might be, or has already been, adversely affected by nuclear energy related facillities was expressed 29 times within the 108 letters.

- From an Oak Ridge resident, "Oak Ridge already has a contamination problem. Two million pounds of mercury released into the environment between 1950 and 1977 , tests in September 1984 revealed radioactivity in underground water on the reservation, 51 million pounds of uranium chips that are burled at the $Y-12$ plant, 7,000 pounds of uranium dust have been released into the air, 125,000 pounds of uranium are burled in trenches (examples continued). WIth this appalling contamination record, DOE is now asking Oak Ridge to welcome the MRS facility to repackage and store nuclear waste from all our eastern states."

- From a Madison resident to Governor Alexander, "I would like to see you demand a general overall environmental study at Oak Ridge. Let us know the honest truth about the damage thats already been done here!" 
- From Lafayette, Tennessee, "We already have too much polson in our streams."

- From a fifth grader at Farm School in Summertown, Tennessee to Governor Alexander, "Please don't pollute our water. I can't grow up drinking sodas. And it's your responsibility to take care of the water and land."

- From Oliver Springs, Tennessee, "I firmly believe in the need for nuclear power. However, there is little public trust ir DOE or their contractors in Oak Ridge. Their environ!nental track record here is horrible. The area creeks are a prime example. Area residents swam in and ate fish from these creeks for decades before being notified that they were 'extremely hazardous'. They have balanced the cost of a new site selection/purchase against the public's right to quality life and safe environment and have chosen 'Easy' over 'Better.' These are the same people that ruined our creeks."

Concern and regard for the safety and public's health of this generation and future generations was represented in the 108 letters twenty times. Examples include:

- From Joelton, Tennessee, "I do not want my children or myself to be a victim of cancer due to exposure to the 'stuff'."

- From Tullahoma, T'ennesse, "There are so many unknowns in nuclear storage that we are threatening our children and grandchildren's lives for hundreds and probably thousands of years." 
- From Hartsville, Tennessee, "We believe that (MRS) could be dangerous to everyone in the community and that it will be harmful to the area."

- From Nashville, "Until our technology for the proper storage or use catches up with this nightmare of nuclear waste we have created, we must not allow Tennessee to become the Nation's dumping ground. Our future and the future of our children and grandchildren are at stake."

- From Knoxville, "We should not jeopardize our state and future generations for a few jobs and a little money."

Closely related to the concern for public health and environmental safety was the anxiety expressed in twenty-five letters that transportation risks and costs are too great to justify the proposal. Examples include:

- From a resident of Nashville, "The matter of safely transporting the nuclear waste to any site in Tennessee is also a major factor in my opposition to the MRS facility. In Nashville alone, it is almost a weekly occurrence to hear of wrecks involving trucks or trains, some transporting hazardous materials. To transport the waste to its final destination would make more sense than having to move this dangerous material twice."

- From Morristown, Tennessee, "I oppose such a facility coming to the Tennessee area because of the transportation hazards it would create. I understand that at least fifteen hundred trucks and one hundred trains a year would be coming to this facility." 
- From Pegram, Tennessee, "Transportation of hazardous waste endangers public safety. There is no guarantee the storage casks are leak-free. Toxins could easily be emitted enroute. The carriers are no longer able to purchase insurance when transporting nuclear waste."

- From Washington, D.C., to the Secretary of Energy, "I am concerned about the nuclear waste that will be transported across my district enroute to the Clinch River site. It has been reported that as much as 15,000 tons of nuclear waste will pass through our state (Tennessee)--twice. Once on its way to Clinch River for processing, then on the way out to a final repository. A DOE official was quoted recently as saying, "the overall risks to which the public is subjected would be reduced under MRS." While that statement may be true for the U.S. population as a whole, it comes at the expense of many Tennesseans who will be assuming a greater risk." ("This letter was copied to Governor Alexander)

- From Signal Mountain, Tennessee, "Last Wednesday, a truck hauling uranium oxide hit a drain in North Dakota. Forty-five people are being tested for possible inhalation of the radioactive material. The MRS would drastically increase the shipment of radioactive waste through our communities. It is inevitable that accidents will happen."

- From Olympia, Washington, "Because of the enactment of the Nuclear Waste Policy Act of 1982, all states will be affected by siting of geologic repositories, the siting of an MRS facility, or the transportation of high-level waste. While only a few will be a repository or MRS state, most states are likely to be "corridor" states for waste transportation. Price-Anderson is a 
complex law designed to compensate for catastrophic accidents. The Act was not designed to cover a repository "slow leak" or the transportation of high-level wastes to an MRS facility or a geologic repository. If the affected states collectively determine that Price-Anderson cannot be amended to resolve the problems, Congress must develop a satisfactory new approach to solve the problems."

Nineteen individuals of the 108 who wrote expressed the opinion that an interim step (MRS) was not feasible and that they felt the nuclear waste should be Inaintained at its present location until it becomes possible to ship it to a permanent geologic repository.

Examples follow:

- From Lenoir City, Tennessee, "There is enough desert land in the western United States to take care of storage facilities without building them in a highly populated area. The DOE has known for years that a permanent storage place was needed and something should have been done about it long ago. It seems a great waste of taxpayers money to go through a temporary storage process."

- From Nashville, Tennessee, "I feel that DOE's energy would be better used in finding and developing a permanent facility."

- From Tullahoma, Tennessee, "We believe the waste should be cared for where it is created. We feel DOE is hasty and irresponsible not to explore further ways of disposing of it on site." 
- From Cosby, Tennessee, "I feel that energy would be more wisely used and tax dollars more wisely spent in finding and developing a permanent facility."

The fear that an MRS facility might become a permanent storage facility for nuclear waste instead of a temporary storage facility was expressed by 22 individuals. Examples include:

- From a resident of Hendersonville, Tennessee, "Once they spend une billion dollars setting this site up, "temporary" (so they say), well be stuck with it forever I believe."

- From Nashville, "Also, I'm afraid the temporary status will end up permanent because no other area wants it either."

- A resident of Murfreesboro, Tennessee, stated, "I believe the Oak $\mathrm{R}$. dge area was selected by DOE solely because it is the only community where it is possible politically to store the waste. If this area is selected, it will eventually be the permanent holding area. Even though we are told that this is a temporary site, surely officials at DOE are astute enough to realize that within ten years if not already, it will be politically, economically, and legally impossible to decide on a permanent site and then move it. No community other than Oak Ridge will accept it. No political leader will approve it moving into his/her district or state. Local and state hazardous substance laws and regulations will proliferate within the next ten years so as to prevent its removal to any other site. Economically, it will become increasingly more difficult to justify the move. Finally, national regulations, liability laws, and potential federal court decisions will keep the waste from ever being removed from Tennessee once it is placed here." 
- From Franklin, Tennessee, "It has been my experience that the Federal government doesn't understand the meaning of the word temporary and once the material is on site, there it will remain. Certainly the pressure will not be as great to find a permanent repository."

Sixteen individuals expressed the belief that an MRS facility would have a detrimental effect on socioeconomic concerns. These reasons include devaluation of property, a discouragement to other industries or families to locate in Tennessee and a loss of tourism. A few examples follow:

- From Knoxville, Tennessee, "It is my opinion that such a facility could hurt economic growth in our part of the state, since I see no way it could be considered anything but a liability by prospective businesses and industries."

- From Hartsville, Tennessee, "I feel that myself or anyone would have a very difficult time selling a business or home to leave a potentially radioactive area to live in."

- Also from Hartsville, Tennessee, "And what about our tourist industry? We spend millions of dollars annually to attract tourism. Now who's going to want to go "Tennesseeing" in the state that houses over $90 \%$ of the nations' nuclear waste?"

Of the 108 who wrote, nine individuals stated among other reasons for opposition to the DOE proposal that they are completely opposed to the development and use of nuclear energy in this country. An example: 
- From a resident of Celina, Tennessee, "Nuclear energy has long been touted as the cure all of our nation's woes. Maybe so. However, there are costs involved in nuclear energy as we all know. One of the greatest is the contamination associated with the wastes. I do not know of any area in this country that would want nuclear waste. In any case, I want my position absolutely and abundantly clear. I am opposed to any storage of nuclear wastes, temporary or otherwise, in Tennessee. I simply do not believe that the benefits of nuclear energy outweigh my concern for my family's health, the quality of life in Tennessee, the protection of our environment, and the health of future generations."

Six individuals stated they felt Tennessee has been selected as a host state for an MRS for the wrong reasons and that the site selection process had been conducted improperly. An example from a resident of Old Hickory, Tennessee:

- "I believe Tennessee was chosen mainly because of two factors: first, some Tennessee politicians have privately told the DOE that they support this decision, and secondly, the people in the Oak Ridge area have grown to tolerate the nuclear facilities and materials already there and may be inclined to accept the MRS more readily than people in other locations."

Of the 108 letters expressing opposition to the DOE proposal, 33 people wrote letters simply stating their opposition to the location of an MRS facility in their town or in this state without giving specific reasons.

Note: Of all the examples given of the various opinions, no two examples are taken from the same letter. 
Letters Expressing Support for the Location of MRS Facility in Tennessee

Several reasons supporting the MRS proposal were presented by the ten individuals who wrote to Governor Alexander and the Safe Growth Cabinet Council. The majority of opinions addressed the socioeconomic benefits. Also discussed were transportation, health, and environmental aspects. Another point was the integral contribution of MRS to a national federal waste management system. A more detalled discussion of these ten letters follows. In regard to possible socioeconomic benefits, three of the ten Individuals expressed the opinion that an MRS facility would provide employment. Examples include:

- From an Oak Ridge resident, "There is no reason to belleve it would be detrimental to this area. The MRS would provide many jobs which are badly needed."

- From a Knoxville resident, "On the positive side, the MRS facility has the potential for significant employment, which is welcome in light of the recent news in Oak Ridge." (K-25 shut down)

Economic gains through individual expansion and spin-off industries were also noted by three of the authors. Examples include:

- From a resident of Knoxville, Tennessee, "For some time, I have been greatly concerned that my leaders may not appreciate that MRS could be the key to major industrial expansion in my beloved East Tennessee." 
- From Nashville, "The MRS represents a billion dollar high technology investment in Oak Ridge. This means hundreds of new Jobs, a design contract for some $\$ 300 \mathrm{M}$, a billion dollar construction contract and 5 to 6 million dollars of operations money coming into Tennessee over the life of the facility. Also, several new spin-off companies are expected to provide many additional jobs in Tennessee."

Two authors noted that the highly trained technical personnel to support an MRS facility are presently located in Oak Ridge and would be encouraged to remain there by the location of a MRS facility.

- From an Oak Ridge resident, "It is also my opinion that the industrial and technical capacity of the east Tennessee area makes it a reasonable place to site such a facility."

The economic benefits and increased tax dollars to the Oak Ridge area was a reason presented by four supporters of a MRS facility. Examples include:

- From Knoxville, "It would also bring in tax dollars which are sorely needed."

- From Oak Ridge, "As is appropriate for all industrial facilities, the proposed facilities should be demonstrated to provide a positive economic gain to the area, and contribute to supporting the surrounding communities through some tax revenues."

The belief that an MRS facility can be operated safely for the environment and not cause harm to the health of the public was expressed by six individuals. Examples include: 
- From a Knoxvlllian, "The technology for safe economical storage does exist. Accidents in MRS facilities that would affect the public are much less likely to occur than those commercial accidents we continually hear about in the news and which have far greater potential for death and destruction."

- From Nashville, "Oak Ridge has an existing site on which 40 to 60 milllon tax dollars have already been spent to qualify the environmental and safety aspects to federal and state regulations."

The issue of safety in transportation was addresed by two of the individuals. One noted:

- "The transportation of spent nuclear fuel has a spotless record. From my understanding of the technical issues, an accident with the unlikely consequence of rupturing the transportation cask would only endanger those few in the immediate vicinity. The cleanup of such an accident would also not require a widespread effort. This is a far cry from the potential hazards of many other 'materials carrled much more cavallerly on our highways today, including propane, gasoline, chlorine, and other toxic substances."

Three of the authors noted that an MRS would aid in solving the need for a national federal waste management system. An example is:

- "On a national level, I am convinced that such a facility is necessary to the welfare of the country. This is based on two grounds. In the first place, we have (and are generating) spent fuel in the process of generating electrlcity for our needs. Such materials should be transported away from the reactors 
and stored for an indefinite perlod. The MRS should provide surge capacity in a central location, thus providing flexibillty in operations and avolding localized problems at certaln reactors, as well as minimizing the transportation miles and all that is associated with them. In the second place, the national interest requires a secure energy supply base. Nuclear energy is one of the necessary elements of our energy supply. There are currently no viable alternatives. A central storage facillty would save system costs over the alternative of providing extra storage of each and every reactor in the country."

One individual noted that contrary to the concern that an MRS facillty might harm the tourist industry in Tennessee that:

- "It will work the other way around, as witness Three Mile Island; it is now a tourist attraction. I'n not sure that east Tennessee needs more tourists, but the point is, an MRS would not keep them away. It would, in fact, attract some."

One individual noted that approval of the MRS is "Imperative to the continuation of nuclear power, a much needed industry for future generations."

NOTE: Unlike the preceding section, several of the comments noted above were taken from the same letter due to the limited availabillty of letters expressing these views. 
Letters Expressing Neither Support nor Opposition, but Providing Information

Four Indlviduals wrote to the Governor or the Safe Growth Cablnet Councll expressing the need for an objective and thorough analysis of the DOE proposal based on factual information. Two examples follow:

- From an Oak Ridge resident to Governor Alexander, "I encourage you to maintain an open-minded posture on thls important issue. As a member of an essentlal government component in this declsion process on MRS, 1 am looking to you to provide the leadership and environment that can lead to a decision based on the truth, an extended opportunity to seek-out and examine the facts and a recognition that we are part of a national activlty of great Importance."

- From an organization In Nashville, "Because of the State role In evaluating and/or approving this project, It is essentlal that any State study program be Independent, comprehensive and challenging of DOE assumptlons. Our best resources must be committed to the study process if the welfare of Tennessee's cltizens ls to be served."

Four other Individuals provided elther newspaper articles or information on leglslation concerning nuclear waste to the Governor to allow hlm the opportunity to better assess the DOE proposal.

Two other individuals recommended to the Governor that should he elect to support the location of an MRS facillty in Tennessee, he should consider requiring the DOE "to establlsh the Oak Ridge Natlonal Laboratory as the center for research and 
development on advance nuclear reactors" as compensation for accepting the MRS faclllty. 


\section{Category II}

\section{Petitions Submitted}

to the

\section{Governor}




\section{General Summary}

Three individuals and one business have submitted petitions to Governor Alexander opposing the location of an MRS facllity in Tennessee as proposed by the Department of Energy. A petition from the Morristown area in East Tennessee contained 100 signatures volcing opposition. A second petition from the Bethpage area contained 139 signatures, all opposing consideration of the Hartsville site. A third petition representing the Nashville-Middle Tennessee area represented 72 Individuals' opposition to the DOE proposal. The fourth petition submitted to the Governor, also representing Middle Tennessee residents, contained 187 signatures.

These four petitions represented a total of 498 different individuals who are opposed to the location of a monitored retrievable storage facillty in Tennessee. 


\section{Petition Summary}

1. Morristown Printing Company, Inc.

"No nuclear waste sites in Tennessee"

Concerned Citizens of Tennessee

Opposes Hartsville and Oak Ridge sites

100 signatures

II. Denel Hicks Petition

Bethpage, Tennessee

Opposes Hartsville site

139 signatures

III. Frank Cochran Petition

"Don't Dump on Tennessee"

Predominantly Middle Tennessee signatures

Opposes Hartsville and Oak Ridge sites

72 signatures

IV. Kate Scurlock Petition

Predominately Middle Tennessee signatures

Opposed Hartsville and Oak Ridge sites

187 signatures 


\section{Category III}

Returned Questionnaires

$-37-$ 


\section{About the Questionnaire}

The Safe Growth Cabinet Council previously developed a "Questionnaire on Monitored Retrievable Storage of Nuclear Waste." This questionnaire was provided

to the public at the four (4) public hearings conducted during August and September. Those in attendance were encouraged to pickup extra copies or copy theirs and to distribute them to friends. The questionnaire contained the following questions:

1. How important is it for state and federal governments to be involved in the proper management of nuclear wastes produced as a by-product of the generation of electrical energy?

2. What are some of the best alternatives for proper management, storage, and long term disposal of nuclear wastes?

3. What are your concerns about the transportation of nuclear wastes from the point of waste generation to the locations for storage or ultimate disposal?

4. What features or characteristics of your community, or features or characteristics of Tennessee, might be affected by transport and handling of nuclear wastes?

5. What are your strongest concerns? 
6. Do you feel that the State (Safe Growth Cabinet Council) process of evaluating the Department of Energy proposal for monitored retrievable storage is adequate to determine all of the assets and liabilities of the DOE proposal? What would you change? 


\section{General Summary}

Sixty-elght individuals completed the questionnaires and submitted them to the Safe Growth Cabinet Council. Another 16 persons did not respond to the questions but did submit their names and addresses in order to be included on the state's mailing list. These questionnaires were provided by the Councll to encourage public involvement and to solicit comments and opinions from individuals.

It was not the intention of the Council to measure merely opposition to or support of the DOE proposal with the questionnaire, although those opinions were quite apparent in the answers. Instead, the intent was to ascertain the alternatives, concerns, and impacts that private citizens might best illustrate in their answers. Questionnaires, with the essay style responses, were analyzed in the same manner as the letters. Thirty-five individuals completed questionnaires clearly indicating their opposition to an MRS facility in Tennessee. (However, it should be noted that two of these individuals also submitted a letter opposing the DOE proposal. Thus, 33 is a more accurate indication of previously unvoiced opposition) of those indicating opposition in their responses, six were from East Tennessee, 17 were from Middle Tennessee, and five are from West Tennessee.

Twenty-six individuals indicated support for the location of an MRS facility in Tennessee in answering their questionnaires. Four had also submitted letters. Thus, 22 is a more accurate indication of previously unvoiced support of an MRS facility. The questionnaires submitted which indicated support for the DOE proposal were all from the eastern part of the state. Another seven individuals appeared neutral in their responses, although one had previously supported the DOE proposal in a letter to the Governor. 


\section{Questionnaire Summary Details}

1. Questionnaires Submitted

No. of Individuals

No comments, request to be included on mailing list

16

Comments Submitted

68

II. Indication of Opposition or Support

Opposition indicated

33 ( +2 who submitted letters)

Support indicated

$22(+4$ who submitted letters)

Neutral, information provided

7

III. Geographic Distribution of Opposition/Support/Neutral-Other

Opposition

No. of Individuals

$\begin{array}{lr}\text { Antioch } & 1 \\ \text { Concord } & 1 \\ \text { Cookeville } & 1 \\ \text { Dixon Springs } & 1 \\ \text { Dover } & 1 \\ \text { Dyersburg } & 1 \\ \text { Hartsville } & 1 \\ \text { Hendersonville } & 1 \\ \text { Kingsport } & 1 \\ \text { Kingston } & 1 \\ \text { Knoxville } & 1\end{array}$


Opposition Con't.

Lancing

Memphis

Murfreesboro

Nashville

Oak Ridge

Old Hickory

Anonymous

Support

Chat tanooga

Kingston

Knoxville

Mt. Pleasant

Oak Ridge

Anonymous

Neutral/Other

Knoxville

Lebanon

Lenoir City

Murfreesboro

Nashville

Anonymous
No. of Individuals

1

5

2

9

3

1

3

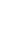

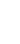

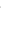

9 
IV. Summary of Geographic Distribution of Questionnalres Submitted

Opposition

Individuals

West

5

Middle

19

East

8

Anonymous

3

Support

West

0

Middle

1

East

22

Anonymous

2

Neutral

West

0

Middle

3

East

2

Anonymous

2 
V. Concerns, Perceptions, and Suggestions .

Should Governments be Involved

No. of Individuals

Oversight is essential $\quad 18$

Federal should dominate, states should support 9

Federal involvement only 9

Both should support, lessen regulatory function 6

No; turn-over to private 0

No; one should abolish nuclear power 3

How to manage, store, and dispose of wastes

Maintaln on site; until shipped to permanent repository 24

MRS is optimal solution 16

Generate less or no waste $\quad 12$

Are 'no' effective means 3

DOE should study more $\quad 2$

Private should do; government should oversee 2

Don't know. 
No concern; Is sate

Truck or train accident

Contamination from radlation

Spllls, leakage

Sabatoge, terrorism

Truck/driver problems

Inadequate $\mathrm{rall} / \mathrm{road}$ systems

Lost shipments, Inadequate regulation, cost efflciency

Efficlent emergency response

\section{Characteristics or features of a community of Tennessee}

that might be affected

Truck/train accldent causing environmental or

public harm

Decreased land values

Negative Impact on tourism

Adverse psychological impacts

Might become permanent

Loss of industry, business and citizens

No effect

Increase of jobs

Improved economy

Improve tax base

Roads would be improved

Maintain people with technical expertise 
Fear of transportation accident-contamination

MRS will encourage generation of nuclear wastes, not best solution

DOE's poor track record

MRS might become permanent

Weak regulatory enforcement abillty

Decreased land values

Unfair site selection

Lost fuel rods

Irrational fear might prevent MRS approval

Interfertence from pollticlans for polltical reasons

Without MRS, reprocessing may never occur

Adequate tax base and compensation should occur

Waste of tax dollars, overstudying the proposal

Safe Grow Cabinet Council process adequate - changes

Evaluation must be objective, thorough and rational

Don't know process well enough to say

"Yes" or "OK"

Evaluation unnecessary, just veto MRS

Don't consider MRS until a permanent repository is sited 
In this section, each question will be presented and followed by answers which lllustrate the majorlty of those submitted or those which are particularly interesting.

1. How important is it for state and federal governments to be Involved in the proper management of nuclear wastes produced as a by-product of the generation of electrical energy?

The opinion most frequently given reflected the bellef that an oversight function is essentlal by both levels of government due to the need to Insure the safe management of nuclear wastes. Elghteen Individuals reflected this view. Examples Include:

- "State and Federal Governinent both must be Involved to provide essential check/balance and protection for the public welfare."

- "Very important. There is no economic gain by the electrical utillties in properly disposing of nuclear wastes. Therefore, the federal and state government must regulate disposal to protect the heal th of the public and the environment."

- "Extremely since the companies exist for proflt and safety has been lower in their priorities. Nuclear waste is a whole new product and concept."

A slight varlation of the previous opinion was stated by those individuals who feel the federal government should dominate the management issue of nuclear wastes while state governments should serve elther a supportive function or as an auditor of the federal government. Examples include: 
- "Waste disposal from commerclal reactors is a national problem and the federal government should take charge of $1 \mathrm{t}$. The states should have only an advisory, helpful role, not an absolute veto. Such Invites Irresponsibility."

- "Because nuclear wastes must be protected for a long time, it is imperative that the federal government take the responsibllity. State government should provide approprlate checks and balances on the Federal governinent's actions."

- "The Nuclear Waste Act of 1982 spells out federal Involvement. The state government should see that emissions from an MRS meet state guldelines. The state usually should not try to second guess the DOE on the need for an MRS."

Nine hidividuals expressed the opinion that only the federal government should be involved and that state Involvement is unnecessary. Examples are:

- Federal involvement is necessary. State involvement is a waste of time and money."

- Federal involvement is important but state involvement is redundant and creates the 'somewhere' else problem."

Six individuals stressed that government should lessen its regulatory role and should Instead be supportive of this "sorely needed source of energy." Another six persons stated the management function should involve neither level of government but 
should be conducted by prlvate-independent agencles to prevent the 'red-tape syndrome'. Three Individuals utillized the question to stress that no one should be involved, that nuclear power should be abollshed. 
2. What are some of the best alternatives for proper management, storage, and long-term disposal of nuclear wastes?

The opinion most frequently provided ( 24 times) was to maintain nucl ar wastes at the nuclear power plants until they could be shipped to a permanent geological repository. An example:

- "Hold nuclear wastes at the generation site, properly package them and ship them directly to the permanent repository."

Sixteen persons felt the MRS facility is the optimal solution, coupled with reprocessing if possible, and final deposition at a permanent repository. An example:

- "Depends on the waste form. Geologic disposal of unuseable, solidified wastes is fine. However, materials such as spent reactor fuel could have considerable value in the not so distant future (e.g., 50 years). As such, 1 favor storage methods such as MRS from which these materials could be retrieved when needed,"

Twelve individuals expressed their view that the best alternative is to generate less waste or to simply not make any more nuclear wastes by ceasing generation of nuclear power. Three persons feel there are 'no' effective means for management, storage, and long-term disposal and two stated that DOE needs to study the problem further before any decisions are made. Two individuals expressed the opinion that a private industry should assume these functions and be regulated by the federal and state governments. Eight people acknowledged a lack of technical expertise to deal with this question and expressed that only those with technical knowledge can adequately address this issue. 
3. What are your concerns about the transportation of nuclear wastes from the point of waste generation to the locations for storage or ultimate disposal?

Twenty-three individuals expressed no concern(s) over this issue. Two-thirds of these did note that they were much more concerned about the transportation of hazardous chemicals. Examples include:

- "Transportation of these materials are known to be safe. There is a 15 year history to prove this."

- "My main concern is that it be done without squandering money on unnecessary safety measures. It would be much more cost-effective to spend our money to improve the safety of transportation of chemicals and explosives. The present safety measures for transportation of racioactive materials are more than adquate."

- "None!!! Transport other materials in as safe and secure a manner as nuclear materials."

The remaining 45 individuals expressed various concerns regarding the transportation of nuclear wastes. Most frequently noted was the concern that accidents might occur endang. ing the health and safety of the public and the environment. The fear of a truck or train accident was noted 24 times. The concern that spills or leakage would occur as a result was expressed by eight individuals. Closely associated was the concern of contamination from radiation which was noted 11 times. The concern that sabatoge or other acts of terrorism might occur was expressed by seven individuals. The need for efficient emergency response was considered by two individuals. 
The concern that trucks might not be properly labeled, that mechanical failures could occur, that drivers might be inadequately trained or careless in their duties was of concern to six of those responding. Inadequate rail and road systems were noted by five persons. The fear of lost shipments, inadequate regulation of the trucks and trains and the question of cost efficiency was noted by four individuals. Examples of these concerns follow:

- "Potential hazards to the public as the results of accidents in the transporting of such wastes through populated communities."

- II am concerned about highway or railway accidents, and feel that the wastes should be transported only once. The possibility of sabotage exists, as well as mechanical problems and driver negligence."

- "Is this going to be efficient? Will some waste be brought from (out west) Nevada to Tennessee (teinporarily) and then taken back out west?"

- "Accidents, leakage, spills, human error"

- "I have very strong concerns about the transportation of nuclear wastes on our highways and railways. It has been hinted that it may be transported on barges which would be another hazard to our rivers. Careless handling, shipping, etc., . . could jeopardize every citizen in our nation. We have grave concern for our local area (Oak Ridge) because of narrow roads, unstable terrain because of caverns and the Rockwood fault zone which hindered the building of I-40. We fear for the safety of our children on school buses." 
4. What features or characteristics of your community, or features or characteristics of Tennessee, might be affected by transport and handling of nuclear wastes?

The possibility of a truck or train accident and associated adverse consequences (possible environmental degradation water, air, and soil and/or danger by radioactive contamination to the publlc) were each listed 17 times. Socioeconomic impacts were also a matter of concern. The concern that land values might decrease following the location of an MRS facillty in their community was noted by four individuals. A negative impact to Tennessee's tourism industry was a concern expressed by six persons. A loss of potential industry and business locations and a reduction of population was a matter of concern to three individuals. Adverse psychological impacts were noted by four persons. The concern that an MRS might become a permanent repository with an adverse impact was noted by four individuals. Examples include:

- "The environnent, water supplies, and the human or wildlife present and to come."

- II feel that people living along the road and highway transportation routes will face increased danger and will lose on their property values. I feel eastern Tennessee will attract less new business and that tourism will be negatively impacted. I am concerned that due to accident water supplies and the air will be contaminated." 
Eleven individuals expressed their belief that there would be no effect(s) to the features or characteristics of their community or state. Six persons noted a potential increase of jobs available and two noted an improved tax base for their community. An overall improvement of the economy was noted by four individuals. Two people expressed a belief that the roads in their communities would be improved. Also expressed by two individuals was the desirability of maintaining people with technical expertise in this area if the MRS facility were to be located in Oak Ridge. Examples include:

- "The MRS would have positive effects for the area with no real negative effects."

- $\quad$ The local economy would be improved and unemployment would be reduced. High technology, support industries would be attracted, particularly robotics and remote handling. The technology corridor would be given another chance."

- None!!! Except to provide jobs and reestablish the use of the expertise that exists in Oak Ridge to properly handle the materials." 


\section{What are your strongest concerns?}

The concern most frequently expressed was the fear of transportation accidents which might lead to the contamination of the environment or endangerment of public safety and health. This concern was expressed by 17 individuals. The concern that an MRS facility might encourage the generation of nuclear wastes and that it is not the best solution to the handling and management of nuclear wastes was listed by 12 persons. The concern that the MRS facility rnight become a permanent repository was noted by seven individuals. What is perceived as a "poor track record" by the Department of Energy was listed as a major concern of nine individuals. Several people also noted areas of concern regarding decreased land values, mismanagement of the facility, lost spent fuel rods, and a lack of enforcement powers to regulate an MRS facility. Illustrations include:

- "My strongest concern is with the possibility of an accident during transport, handling and/or storage. DOE can make perfect plans but they can't make human beings perfect. And the MRS could be a permanent dump. The GAO has already said there won't be sufficient funds to build both an MRS and a permanent repository simultaneously."

- "That the quality of life will be adversely affected through human error or mechanical failure or 'Acts of God' while transporting or holding such wastes through or in our community."

- "My community being perceived as a waste dump." 
- "Past record of Federal Department of Energy at Oak Ridge in handling nuclear wastes."

- "On the other hand, DOE has a record of starting large projects and not completing them. Negotiations should seek to obtain a commitment from the DOE to complete and operate an MRS-not merely to start it."

Others expressed concern that Irrational fear and hysterla might prevent the approval of the DOE proposal. Twelve individuals volced this opinion. Elght persons fear that interference by politiclans for political reasons might harm the chance of an MRS facility being located In Tennessee. Two individuals voiced the concern that without an MRS facillty the chances of reprocessing nuclear wastes might be diminished. Two other persons voiced concerns that an adequate tax base and compensation be awarded the host community. Finally, two persons expressed concerns that tax dollars might be wasted by over-studying the proposal or by unnecessary escorting of trucks transporting the waste. Samples of the above concerns:

- $\quad$ My strongest concern is that state and local officials will be swayed by antinuclear hysteria (much from outside of Tennessee) and will cause the DOE to locate the MRS elsewhere. Knowledgeable and responsible citizens are not being heard, because they do not make controversial and sensational statements."

- "That politicians are exploiting the MRS issue to fur ther their own careers."

- "That the valuable spent fuel be given a permanent storage/disposal before reprocessing. That is: reprocess the fuel eventually." 
6. Do you feel that the State (Safe Growth Cabinet Councll) process of evaluating the Department of Energy proposal for monitored retrlevable storage is adequate to determine all of the assets and llabllities of that DOE proposal? What would you change?

The majority of the persons responding to this question, even lf they were unaware of the actual process, emphasized the need for the evaluation process to be thorough, rational, objective, unblased and based on factual information. This suggestion was noted by 19 individuals. Seventeen persons commented they were not knowledgeable enough about the process to determine its adequacy but many of these did emphasize the suggestions above. Twelve individuals simply replied "yes" or "okay." Of those responding that the process is not adequate, six sald the evaluation is not necessary because the people of Tennessee simply do not desire an MRS facillty in this state. Six noted they feel the evaluation should not be conducted until a permanent repository siting is more definite. Three expressed the belief that the process is unnecessary and a waste of tax dollars and the MRS facllity should proceed into construction without further delay.

Changes and suggestions covered a broad range of views. Six individuals suggested an increased involvement and assistance by technical experts in this area to provide a broader range of knowledge. Five individuals expressed concern that the State is evaluating the "need" for an MRS and that the State should not be able to veto the proposal to Congress. The opinion that these are "federal" not "state" decisions was emphasized. On the other hand, four persons noted their objection to the "simple majority override" avallable to Congress and an inadequate time perlod and information from DOE to thoroughly study the proposal. Six individuals criticized the Council for insufficient notification and announcements of the 
hearings and for not making the public more aware of the DOE proposal. Six others volced criticlsm of publlc officlals for beling too vocal of their own oplnions, for utillzing the MRS to advance polltical careers and for falling to maintain an objective stance on the issue. Some examples of the above are noted:

- "In general, 1 agree that the Councll (or Its equivalent) should objectively evaluate the proposal and negotiate with the DOE. Certainly, the decision should not be based on medla accounts and polltical rhetorlc."

- "I am not opposed to any process that investigates MRS in an unblased, intelligent manner."

- $\quad$ "Spend less money for the evaluation because the MRS is politically unpopular in Tennessee and less information should be needed to form a correct decision."

- "The DOE itself does not yet have a genuine plan there to evaluate because the purposes and periods of use remain indefinite and will until a permanent facillty is devised."

- "Junk it. Existing regulations and bodies are adequate to assess Impacts."

- "Should enlarge expertise with more studies and input from technical experts from Nashville - University - Community."

- "The mandate to review the need for the MRS is wrong. Need should be decided by the federal government and should not enter into the state's deliberations." 
- "Congress' power to override the whole thing via a simple majority makes me feel that this is an exercise in futllity."

- "Nol Very little publlcity has been given to this virtually important issue, Most of the people in our state are unaware that Tennessee is the site proposed. I belleve that if they were informed properly they would be telling you that we do not want this facillty bullt here."

- "I would certalnly eliminate all office seekers from the Council as having a basic confllct of Interest."

- "I think so. You need to support the creation of a local board to oversee MRS." 
Category IV

Public Hearings

$-60-$ 


\section{About the Hearings}

In the atternpt to provide a focus for publlc attention on the MRS lssue, the Safo Growth Cabinet Councll sponsored four public meetings across the state. The public meetings were held in locations which provided reasonable access to major population centers, potential MRS sites, and projected waste transport routes. The flrst publlc hearing was conducted on August 20, 1985, in Chattanooga. A second public hearing was held two days later on August 22nd In Knoxville. The third publlc hearing was held in Lebanon on August 29, 1985. The fourth hearing was conducted on September 5, 1985, In Memphis.

The purpose of the public hearings was to include the public in the State's process to evaluate the DOE proposal on MRS. The hearings provided an opportunity for DOE to present the MRS proposal to the public and for State officlals to explain the process by which the State would evaluate the proposal and to recelve comments and questions from the public. The public was invited to speak to any part of the proposal and to submit any written comments they might have for consideration. 
Publle Hearlng Summary

1. Attendance (approximated).

$\begin{array}{lr}\text { Chattanooga } & 45 \\ \text { Knoxville } & 100 \\ \text { Lebanon } & 90 \\ \text { Memphis } & 65\end{array}$

II. Number of Speakers

$\begin{array}{lr}\text { Chattanooga } & 8 \\ \text { Knoxville } & 19 \\ \text { Lebanon } & 25 \\ \text { Memphis } & 12\end{array}$

III. Attitudes Expressed by Speakers

Oppose Favor $\quad$ Other

$\begin{array}{lcll}\text { Chattanooga } & 4 & 1(+2) & 2 \\ \text { Knoxville } & 9(+1) & 5(+3) & 4 \\ \text { Lebanon } & 15(+10) & 0 & 0 \\ \text { Memphis } & 10 & 0 & 2\end{array}$


IV. Reasons/Oplnlons Glven for Opposition (verbal and written)

Individuals

Transportation risks and costs 12

MRS might become permanent

DOE "track record"

9

No "need" establlshed

8

Maintaln waste on site, then ship to a permanent repository

Pollution of enyironment

Adverse socioeconomic Impact

Public health and safety

Improper site selection

May divert construction of a permanent repository

V. Reasons/Opinions Given for Support

Provide employment

Transportation is safe

Can be operated safely for the environment and public

Retention of technical expertise

in Oak Ridge

2

Increased tax base

1

Aid the technological corridor's advancement

Enhance tourism 


\section{Chat tanooga Public Hearings}

The first public hearing was conducted on August 20, 1985, at 7:00 p.m. at the Chattanooga State Technical College. Approximately 45 members of the public and the media attended the hearing. Following an explanation by Commissioner James Word of the hearing objectives and agenda, DOE representative Keith Kline presented the MRS proposal to the public. Mr. Ben Smith and Mr. Wayne Scharber, both state officials, then explained the process by which the executive branch plans to evaluate the proposal.

The floor was opened to the audience following the official presentations. Eight persons spoke and a ninth person submitted written comments only. Of those individuals making presentations, three individuals favor the location of an MRS facility in Tennessee, four oppose it, and two persons are neutral with specific concerns and opinions being presented for consideration.

Two of the three individuals supporting the proposal by DOE also submitted letters or questionnaires which have been reported in previous sections of this report. Reasons presented included:

- "MRS will provide economic benefit, directly and through spin-off industries."

- "It will provide a solid anchor for the Technological Corridor."

- "It will be an environmentally safe industry posing no threat to the public."

- "Methods of transportation are proven and safe" 
Four individuals spoke in opposition to the DOE proposal. These individuals' comments are not included in other sections of this report. Opposition was expressed for the following reasons:

- "There are too many unanswered questions concerning adequate environmental safeguards, length of life time of the MRS, its effect on a long-term facility, and on-site storage."

- "Public safety risks and the cost of the facility, including the amount of the grant to Tennessee in an era of national deficits."

- "Transportation accident probability will increase."

- "On-site storage is a preferred option."

Two citizens presented concerns and questions regarding public safety, monitoring requirements, oversight authority and the need for recycling and that people should be cautious against "speaking out on some things we don't really understand."

The ninth individual submitted written comments stressing the need for a "rational and uniform basis to evaluate and deal with cost-benefit decisions on MRS and the possible safety implications, along with other potentially hazardous industries." (A questionnaire was submitted by this individual using similar language.) 
Knoxville Public Hearing

The second public hearing was conducted by the Safe Growth Cabinet Council on August 22, 1985, at 7:00 p.m. at Farragut High School in the main auditorium. Approximately 100 people were present. The hearing was opened and proceeded as the one previously described at Chattanooga. Nineteen persons made statements or asked questions and four people submitted written comments without making an oral presentation. Of the 19 persons who made statements or asked questions about MRS, ten specifically expressed opposition to the MRS, five specifically supported the MRS, and four people stated no specific positions. Four persons submitted written support of an MRS facility in Tennessee.

Four of the nine individuals expressing support for the DOE proposal have had their comments included in the questionnaires, letters, and Chattanooga hearing sections. Therefore, a more accurate indication of previously unvoiced support came from only one individual. Reasons presented in support of MRS included:

- "advancements for the Technological Corridor"

- "no significant hazards to the public"

- "substantial economic benefit"

- "transportation casks are safe"

- "rods are insoluble 'as all get out'"

- "DOE's track record has been overemphasized. We are judging by today's standards and knowledge on things that happened 20-30 years ago."

- "increase in traffic will be insignificant"

- "MRS could be a tourist attraction"

- "it may be an invalid role for the state to determine the 'need' of an MRS" 
- "there are other much more significant issues we should be concerned about instead of MRS"

Ten individuals spoke in opposition of an MRS. One of these individuals also expressed concern in a questionnaire, thus nine is a more accurate indication of previously unvoiced opposition. Reasons provided include:

- "The possibility of terrorist attacks upon shipments and the damages that could ensue."

- "DOE information to the publlc does not reveal design details for construction of shipping casks."

- "It is more practical and efficient to store on site."

- "The transportation risks are too great to outweigh any benefits"

- "State Highway No. $58 \mathrm{~N}$ is an unacceptable route"

- "Site selection was not done properly and a need for the MRS has not been demonstrated"

- "DOE's environmental track record is too poor to consider an MRS. Their cavalier attitude towards citizens is astounding"

- "MRS may become permanent" 
- "Decreased land and home values/tourism"

- "East Tennessee needs to wean itself from the Federal government."

- "Concern for public and environmental safety"

Those four individuals whose comments, written and verbal, fall into the neutral/other category included questions and comments about:

- additional time to study the MRS

- is a referendum available

- funding roles

- the State's evaluation procedures

- availability of compensation in the event of an accident

Four individuals submitted written comments in support of the DOE proposal citing:

- economic benefits

- technical expertise exists already

- the need for an effective management plan for construction, operation, funding, and eventual shut-down of the facility should be provided as part of the proposed package

- compensation occur to the host community 
Lebanon Public Hearing

The third public hearing was held in Lebanon on August 29, 1985, with approximately 90 persons in attendance. Twenty-five individuals spoke during the meeting. All those who spoke expressed opposition to the DOE proposal. Many of the reasons voiced in opposition of an MRS facility in Tennessee have been cited previously in this report. These will all be tallied into the summary, if not quoted specifically. Ten of the 25 who spoke have also submitted questionnaires or a letter. Thus, 15 is a more accurate indication of previously unrecorded opposition. The following illustrates some of the concerns that have not been frequently noted in this report:

- MRS is the creation of a "work project for DOE."

- The issue is just "too political."

- Why did Tennessee get all three proposed sites?

- "This re-packaging concept was developed by DOE not Congress."

- Will defense wastes or foreign wastes come to an MRS in Tennessee?

- DOE can expand tonnage amount per year (to 70,000 tons) without Tennessee being able to prevent the increase.

- DOE did not adequately include Tennessee in the planning stages.

Four persons also asked questions concerning liability insurance, decline of home and land values, the possibility of MRS landing in the court systems, and whether anyone is studying the possible impact on tourism.

Several of the speakers voiced criticism that the Council had not adequately provided notice of the hearing to the public. Several voiced that, "the meeting had 
been kept a secret" and that "inadequate notice had limited the attendance." This criticism will attempt to be corrected in the second serles of meetings by additional announcements and media coverage. 
Mernphis Public Hearing

The fourth public hearing was conducted on September 5, 1985, at the Memphis Convention Center at 7:00 p.m. The hearing was attended by approximately 65 people and was opened in the manner described in the previous meetings. Twelve individuals spoke during the meeting. Ten expressed opposition and asked questions concerning the DOE proposal and the other two individuals posed questions to DOE.

The reasons for opposition are similar to those expressed by others during previous hearings. Examples include:

- "The need for an MRS facility has not been documented sufficiently."

- "DOE has a creditability problem and has shown callous disregard to Tennesseans and their environment."

- "DOE has said the power companies will bear the burden of expense. That is bologna."

- "An MRS may delay decisions regarding a permanent repository and in fact become a permanent facility."

- "The transportation of nuclear wastes involves too great a risk to justify an MRS." 
Questions posed to the DOE representive Included:

- What will be the exact figures, amounts, and methods of transporting nuclear wastes through Memphis?

- What "safeguards" is DOE proposing to prevent the MRS from becoming a defacto permanent repository?

- Are millitary or foreign wastes going to be recelved and handled at an MRS in Tennessee?

- Can plutonium be extracted from the nuclear wastes to be recelved at an MRS?

- "Why does Tennessee have all three candidate sites and the rest of the country none?"

The criticism that the public hearings had been insufficiently publicized was noted by one speaker. Another speaker did comment that he was impressed with the knowledge and level of expertise demonstrated by the officials on stage, particularly in comparison to hearings he recalled from 1982 regarding the Nuclear Waste Policy Act. 
Category V

\author{
Media Coverage and \\ Notification to \\ the Public
}


The Safe Growth Cabinet Councll was crlticlzed during the publlc hearlngs concerning a lack of public notlfication about the MRS Issue and about the hearings themselves. The purpose of this section is to let you know that we have, with the aid of the news media, attempted to inform the cltizens of Tennessee of DOE's proposal and of Governor Alexander's desire that you be a part of the process of evaluation.

A press release was made on August 12,1985, announcling the public hearings that would be held in that month and in September. It named the locations and dates of the four hearings and emphasized that the hearings were designed to gather citizen views and to share information on the U.S. Department of Energy (DOE) plan to locate the nuclear waste handling and storage facillty at one of three recommended sites in Tennessee. The news release explained when and where the public forums were to be conducted, the participation of DOE officials, the role of the Safe Growth Cabinet Council in the evlauation process, and the Importance of gathering the public's attitudes on this subject. This press release was malled to 75 newspapers. Copies of 32 articles announcing the hearing prior to the hearing dates have been compiled by the Council. The press release was also mailed to 36 television stations, 112 radio stations, 22 state agencles (including local health departments), 23 elected officials (including representatives, mayors, and local of ficlals near the host communities). Many elected officials also received courtesy phone calls to remind them of the publlc hearings and to ask them to spread news of the hearings to their constituents. Fifteen representatives of private industries and 14 environmental organizations or their representatives recelved notices of the hearings. 
The Safe Growth Cablnet Councll has also attempted to compile a notebook of the coverage concerning MRS that has occurred In the newspapers across the state. We feel certain we have been able to compile only a fraction of the articles that have been written concerning MRS. We have, however, complled over 280 artlcles pertaining to the MRS Issue that have been published in newspapers across the state since April of this year.

It is the Governor's desire that Tennesseans be both aware and knowledgeable of this issue. Governor Alexander also wants to know how citizens of Tennessee percelve this issue and to hear their opinions. In order to achleve these goals, four public information meetings will be held during the first two weeks in December, 1985. The meetings in December will provide the State an opportunity to dellver an analysis of what they have learned to date concerning the DOE proposal and to afford the public a chance to ask questions about those findings.

The above noted attempts to inform and include each citizen in Tennessee in our evaluation process may not have been adequate. We will endeavor to broaden our scope of publicity and public announcements prior to our second round of public meetings. Your assistance through talking to your neighbors, co-workers, frlends, and relatives concerning the DOE proposal, its possible assets and liabillties will help. Please encourage all to communicate their opinlons to Governor Alexander or the Safe Growth Cabinet Council. 
Category VI

Resolutions

$-76-$ 
Several groups of Individuals, organlzations, munlclpallties, and county commlssions have passed resolutions opposing the location of a Monltored Retrlevable Storage facillty in Tennessee. A copy of the resolutions passed are Included. A list of these Include:

1. Cannon County Commission

2. Cumberland County Medical Soclety

3. Rotary Club of Jamestown

4. Slerra Club, Tennessee Chapter

5. Tennessee Conservation League

6. Tenriessee Environimental Councll

7. Polk County Commission

8. Obion County Commission

9. Church Women United

Five additional county commissions have indicated their interitions to pass resolutions in opposition of an MRS during the month of November. Copies of these wlll be provided in the flnal report in January 1986.

The Mayor and Councllmen of the Clty of Oak Ridge and the Roane County Commission have both passed resolutions adopting the position and recommendations of the Clinch River MRS Task Force presented in their report of October 10, 1985. 


\section{Cumberland County Medical Society \\ P.O. Box 2973 \\ Croseville, TN 38555}

October 24,1985

The Honorable Lamar Alexander

Governor of Tennessee

State Capitol Building

Nashville, TN 37219

Dear Governor Alexander:

on september 26, 1985 the Cumberland County Medical Society convened and voted unanimously to contact their representatives in the Tennessee General Assembly and the Congress of the United States, as well as the President of the United States, the Governor of Tennessee, and various other elected officials in order to make them aware of the Society's opposition to the establishment of an MRS facility (nuclear waste dump) in Oak Ridge, Tennessex, Furthermore, the society elected to oppose the establishment of any such facility in any location in the state of Tennessee.

The reasons for their opposition to the establishment of such a facility are as follows:

(1) The facility would pose a definite potential health hazard to the citizens of Knoxvilie, Chattanooga, and all of East Tennessee. Regardless of the assurances that there would be no danger, past experience has not borne this out and multiple accidents have occurred.

(2) The act of transporting nuclear waste to and from the facility in itself constitutes a hazarci and would predispose to a vastly increased traffic accident rate.

(3) The area is a highly populated, rapidly developing araz, and the thought of locating a facility of this character in such a densely populated area is unreasonable and further enhances the danger to the citizens of East Tennessee.

(4) The water table is high in this area and the chance of contaminating the cities downstream from the facility would lso pose a threat. The city of Chattanooga and Hamilton County constitute a highly populated area and the major impact would be on this area. 
Governor Alexander

Page 2

(5) There is a possibility the facility, though it is described as a "temporary storage facility", would become the permanent storage site. In our opinion, for the reasons innumerated above, either a temporary or permanent facility is unacceptable.

(6) There are many sites in the United States with little or no population, vast areas without vegetation, a low water table, no traffic problems, and ample storage sites which would lend themselves to a permanent storage facility.

(7) In our opinion, the establishment of a permanent storage facility would eliminate the necessity for a temporary facility as well as eliminating the unnecessary expenditure for such a facility.

Governor Alexander, our Society respectfully requests your assistance in restraining the establishment of a nuclear waste dump in the state of Tennessee.

1<smiles>[TeH]</smiles><smiles>C1CCCC1</smiles>

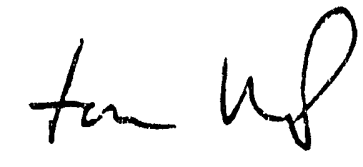
ienct gyen, nes

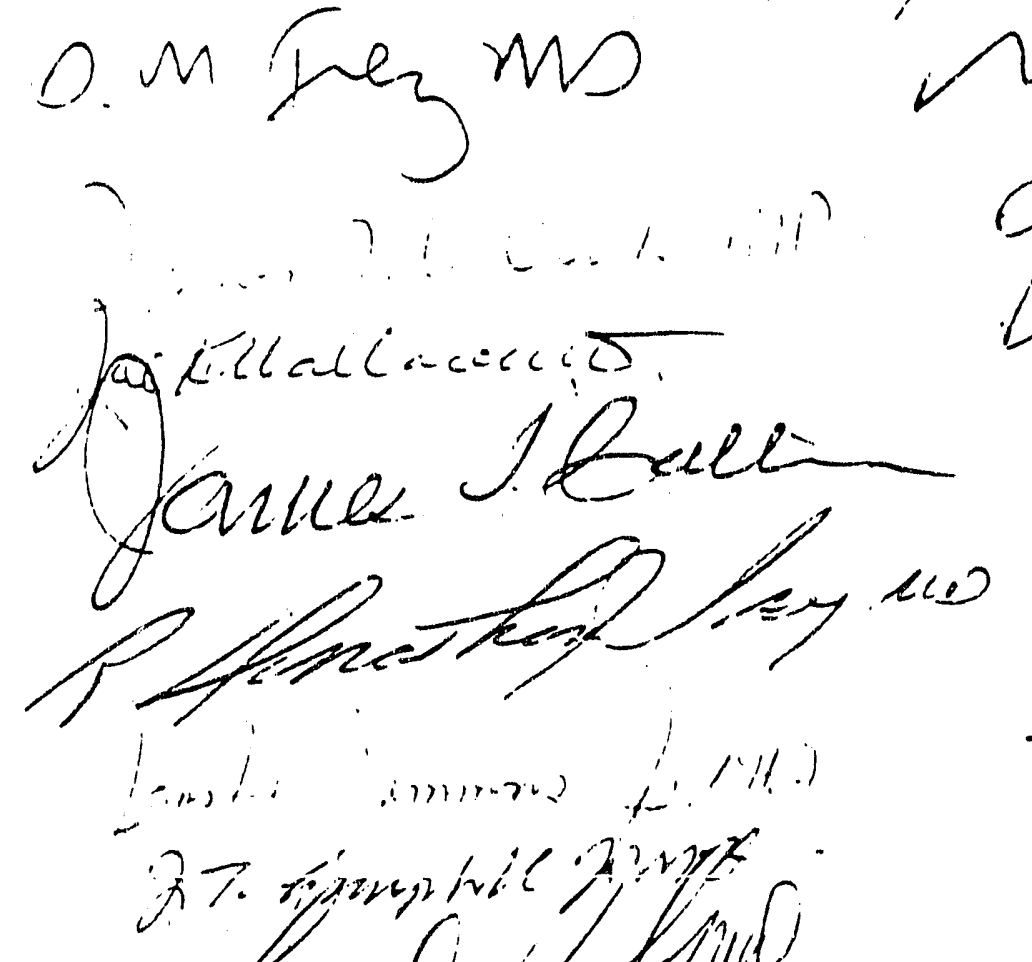

sincerely yours, 


$$
\begin{aligned}
& \therefore \text { ( } \\
& =C \operatorname{lol}
\end{aligned}
$$

Phelig D. Decttivenge

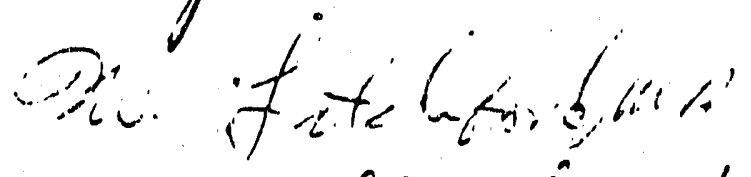

4hisilat folus her

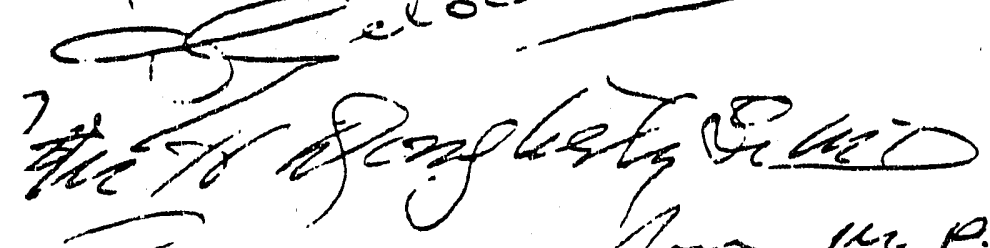

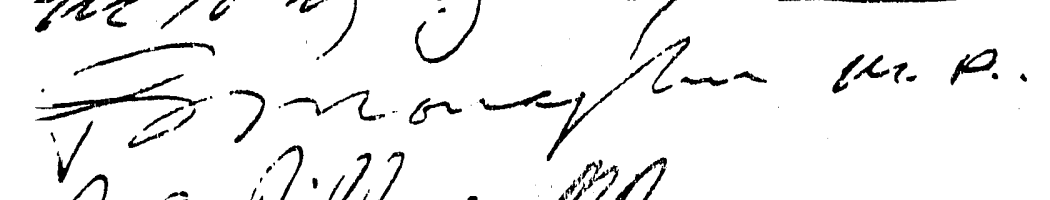

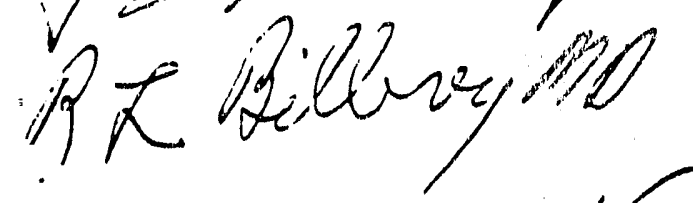

Zuderonusse. il

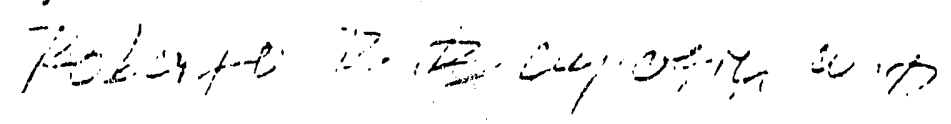

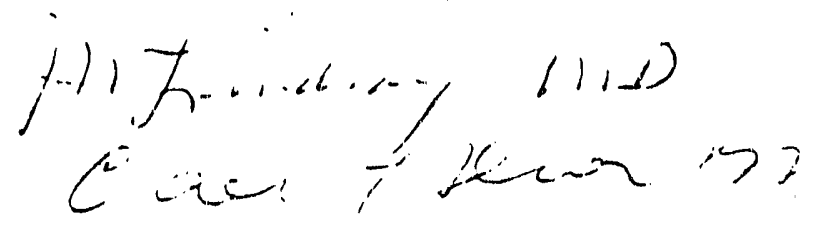


ROTARY CLUB OF JAMESTOWN, INC.

AMESTOWN TENNESSEE 38536

15 October 1985

TO: Governor Lamar Alexander

State Capitol

Nashvilie, Tennessee 37215

SUBJECT: DOE MRS PrOPOSAl

Dear Governor Alexander.

A majority of the nembers of the ROTARY CLUB OF JAMESTOWN, TENNESSEE wish to express their objections to the Department of Energy's proposal to establish a Monitored Retrievable Storage Facility (MRS) in Tennessee.

It 1s the conclusion of this organization that DOE has not demonstrated the need for such a facility nor has it demonstrated the safety of either the atorage or transportation of the nuclear waste involved. We concur with the judgement of TVA that the facility is not needed and its conatruction and operation would be waste of money. As to the lasue of danger to the public, it is the conclusion. of this organization that there 1 s littie likelihood that DOE will ever be capable of demonatrating safety to the degree necessary for a change in the public perception of the problem. Thus, if the proposed MRS Facility is approved. It $1 \mathrm{~s}$ our determination that Tennessee will become known as the Nuclear waste Dump of the Nation.

such a conclusion by the people of this nation will cause the economy of Tennessee to suffer irreparable harm. The Tourlat Industry especially will be severely impacted. The ninimal favorable economic impact of the MRS facility will not be auflcient to justify the economic liability of auch a facility to the rest of the economy.

we request that you take those actions authorized by law to resist the establishment of this unneeded and unwanted facility.

Sinceredy,

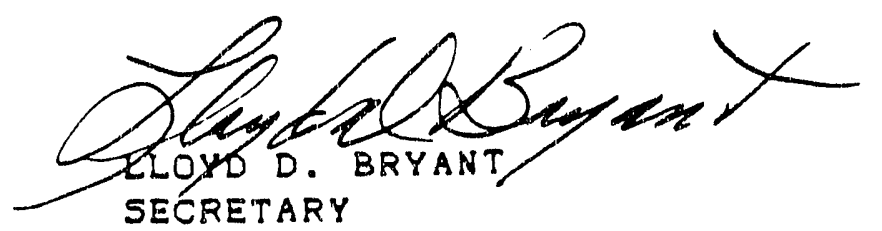

LLOYD D. BRYANT

RR 1 BOX 239

CLARKRANGE, TENN

38553 
A Resolution by the Sierra Club, Tennessee Chapter, on the Proposal by the Department of Energy(DOE) to Construct a Monitored Retrievable Storage Facility (MRS) in Tennessee.

\section{RESOLUTION}

Be it resolved that the DOE having failed to establish the need or desireability of a centralized MRS, the construction of a centralized MRS in Tennesse, or in any other state, shall be opposed; 
Rasolution of the

Board of Directors of the

Tennessee Enviranmerital Couneld

In regard to a proposal of the U,S. Department of Energy to construct a major facility in Dak Pldge, Tenmessee for the purpose of recaiving, repackaging, storing, and reshipping spent nuclear fuel from commerclal generators, high level commercial wastes, high level defense wastr and/or wastes from the reprocessing of ruelear Fuel, the Board of Directors of the Tennessee Envirommentad Counfad findas the foldowing:

The Department of ifogls has shown inadequate aconomic, selon. tifle or technitui palis for its decision to investigate only

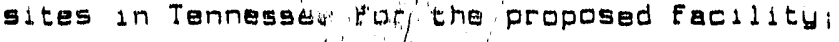

The Department of Energy was been directed by Congregs in the Nuclear Waste Poldcy Act of 1992 to estabilish a permanent geologie repository for the nation's spent fued, but that tash: has been mada almost impossible bu the political capabilities of host states;

The current proposal for Dat: Ridge appears to be in response to poldtical rather than technical or economic requirements:

It can be demonstrated, and D.D.E. representatives houe themselves conceded, that it is technically faasible to provide for storage of nuclear materials at the plants until a permanent repository is avaldable;

Tennessee's own nuclear generator, the Tenmessee Valley Authority accepts the practicality of on-site storage, as evidenced by comments of Manager of Power Hugh L. Parris in responge to the D. D,E. Dlanrisng doeuments:

D.Q.E. is unlikely to meet its schedule for establishirg a permanent repository, but should devotefull attention to developing a repository as expediently as possibla, and construction of an interim facility can only divert resources from the core program;

D.D.E. cannot offer concrete assurances on what the long term uses of the faclilty may be, including handling of defense or reprocessing wastes and the repactaging and storage of materdals for the second repository:

Existing D.Q.E. nuclear Facilities in Dak Ridge, and elsewhere in the nation, have created severe soil and water contamination which should be corrected before any additional facility is considered;

Cdtizens of Tennessee are extremely concerned about potential impacts from the transportation of nuclear materials through their communities, and there is not a clear consensus throughout the nuclear community about the severity of routine or accidental releases of radiation from such trangportation.

Therefore, the Board of Directors of the Tennessee Envirorimental Councid, meeting in Nashville on September 17, 19e5, resijive to oppose the construction of the proposed nuclear repackating plant in Tennessee or in any other state. 
.. That the future may know the bounties of our past

\section{Tennessee Conservation League}

1720 WEST END AVE, SUITE 300

N,ASHVILLE, TENNIESSEE 37203

(615) 329.4230

\section{RELATIVE TO THE MONITORED RETRIEVABLE STORAGE OF NUCLEAR WASTES IN TENNESSEE}

WHEREAS, the Monitored Retrievable Storage of nuclear wastes is proposed for a location in Tennessee could have a significant impact on Tennessee's environment; and WHEREAS, the Department of Energy, the Tennessee Congressional delegation and the Tennessee State Government are currently conducting studies to determine if the Tennessee sites are adequate; and

WHEREAS, many members of the Tennessee Conservation League and many Tennessee citizens are very concerned about the location and operation of the Monitored Retrievable Storage faclity.

NOW, THEREFORE, BE IT RESOLVED by the members of the Tennessee Conservation League Board of Directors, assembled in Cookeville, Tennessee, on October 12, 1985, that TCL hereby urges the Tennessee Congressional delegation, the Governor of the State of Tennessee, and the members of the Tennessee General Assembly to oppose the location of the Monitored Retrievable Storage facility in Tennessee until:

1. Permanent storage facilities for nuclear wastes are located and developed.

2. Current environmental problems associated with D.O.E. operations at Oak Ridge are satisfactorily resolved.

3. The D.O.E. is able to document the necessity of developing a Monitored Retrievable Storage facility. 


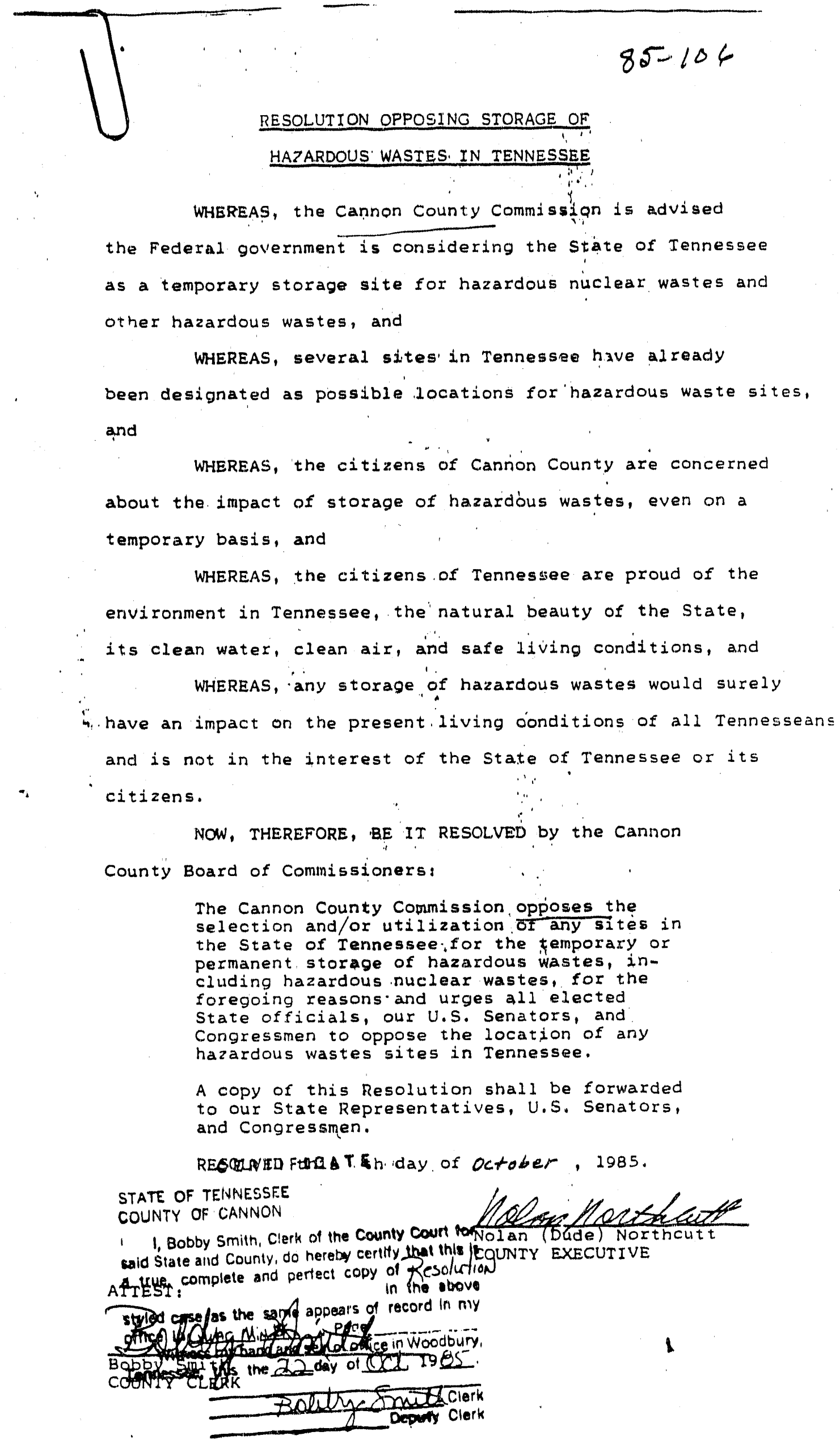




\section{CERTIFICATE}

\section{STATE OF TEINNESSEE. \\ COUNTY OF CANNDIN}

1, Botby Smith, Clerk of the County Court for sald State and Councy, do hereby certify that this s. a true. complete and periect copy of Rescluticn a true. complete and periect copy in the above
styled case as the same appears of record in nyy office in Guec. Min LK. Pare Witress my hand and sea of rice int 1985. Iennessee, this the 72 disy ot

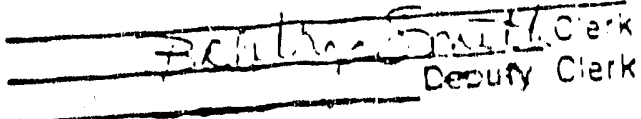




\title{
Church Women United
}

\author{
Nashville, Tennessee
}

\section{RESOLUTION}

Thereas -Church Women United in Tennessee has had a long time interest in nuclear power and its consequences for our society; and in 1974 passed a resolution opposing construction of more nuclear power plants until problems of leakage, of radiation, of serious accidents, and of the disposal of dangerous high level muclear wastes were solved; and

Thereas -Since that time all nuclear reactors have continued to accumulate their used highly radioactive fuel rods at the reactor sites for temporary storage, but no plan has been found for their permanent disposal, and

Whereas - In 1982 Congress passed a "iuclear Waste Policy Act" making the Federal Department of Energy (DOE) responsible for providing permanent disposal for these used fuel rods by 1998 , but in the meantime reactors are running out of space to store these wastes, and DOE is now proposing a temporary facility called an NRS (Monitored Retrievable Storage) to be located in Tennessee, and Thereas - The danger of accidents during transportation to Tennessee from all sections of the country, the cost of moving these wastes twice, and the possibility of Tenressee being turned into the permanent repository for these highly radioactive fuel rods all need to be considered --

iherefore

Church Women in Nashville opposes the Monitored Retrievable Storage plan, and urges that the utilities be required to keep their used fuel rods on their present sites until the permanent storage facility is available.

\section{- United States Senators}

Jim Sasser

298 Russell Senate office Building

Washington, D.C. 20510

Nashville office: 251-7353
Albert Gure, Jr. 225-A Hart Senate Building Washington, D.C. 20510 Nashville office: 251-5129

\section{United States Representative, 5th Congressional District}

\section{Bill Boner}

11: Cannon Building

Washington, D.C. 20515

Nashville Office: 522 U.S. Courthouse 37203

Phone: 251-5296 
A RESOLUTYON TO OPPOSE THE LOCATIUR OF A NUCI.EAR OR IIAZARDOUS WASTE DUMP IN THE STATE OF TENNESSEE

WHEREAG, there 1a an effort by the Undted States Department of Energy to locate a nuclear or hazardous waste dump within the stata of Tennessee; and,

WHEREAS, large numbers of citizens of Polk Councy. Tannessee. have expressed to the various County Commisstoners of their concern and apprehension over the location of a nuclear or hazardous waste dump within the state of Tennessee and are opposed to the same; and,

WHEREAS, tt appears that the locating of a nuclear or hazardous waste dump within the state of Tennessee would subject the cltizens of Polk County, Tennessee, as well as the citizens of the entire state of Tennessee to unreasonable exposure to deach or infury that could result from accldents, occurances, and acts of cod with respect to the dumping. and transportation of sald hazardous materials; and,

WHEREAS, 1t appears to the County Commisston that more remote and desolate areas of the Untied states could be used more safely and efflciently than the heavily populated state of Ternessee; and,

BE IT, THEREFORE, RESOLVED, by chis County Comission of pulk County. Tennessee, in regular session assembled on this 15th day of August_____ a majortity or more of the nembership of said Commistion concurring, that the United States Senators Albert Gore, $3 r$, and James Sasser, as well as United States Congressman John Duncan he and are hereby requested by this County Commission that they use all of their influence and position to keep any nuclear or hazarduus haste dump site from being located in the state of Tenriasee and to vote agalust the location of any such site in the state of Tennessee.

BE IT FURTHER RESOLVED, that the County Executive, Charles E. Stevens, be and is hereby authorlaed and requested to forward a copy of the Resolution to Senator Albert Cone, Jr., Senator James Sasser and Congressman John Durican.

Hoyt T. Firestone, Chairman

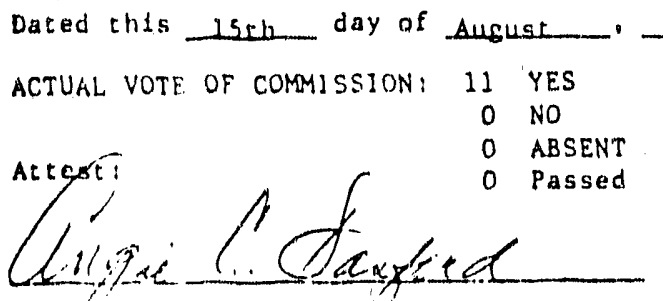

Ang bici. Sinford, Coutry clerk 


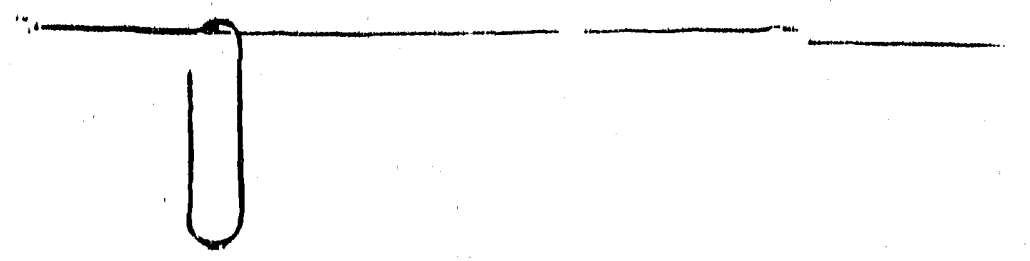

RESOLUTION

WHEREAS, the U. S. Department of Energy 1o planning

to select a site for a Nuclear Waste Dump in Tennesgee whloh wild, directly or indirectly, adversely effect the quality of life of the residents of Tennessee; and

WHEREAS, the unreasonable proposed federal dumping of highly radloacive nuclear waste, from 94 privately owned companies from other states, would make our state the nuclear wase dump for the nation,

NOW, THEREFORE, BE IT RESOLVED by the Obfon County Conmission that the efforts of Publlc Service Combasioner Frank Cochran to stop the Federal Government from making our atate the nuclear waste dump for the nation are supported by this County Coumission. BE IT FURTHER RESOLVED that the County Clerk send copies of this Resolution to President Ronald Reagan, Senator Albert Gore, Jr, Senator Jim Sasser, L, S. Congressman Ed Jones, State Representative John Tanner, State Senator Milton Hamilton and the local news media.

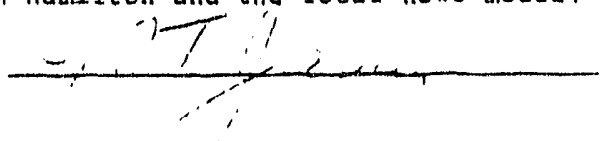

ATTEST:

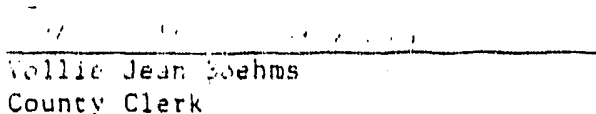

$\leq[\wedge L$

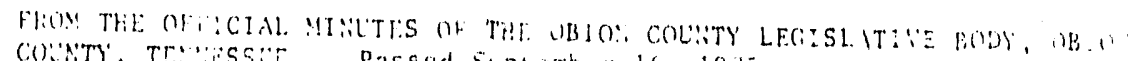

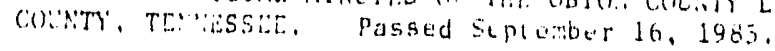




\section{RESOLUTION}

WHEkEAS, the Auclear Waste Holicy Act of 1982 calls upon the Lepartilent of energy (LUE) to prepare recomulendations regarding the neted tor and localdun ol Monilored Kelrievable storage (Mks) facillitius to handle spent nuclear tuel destined tor perwanent repositories, and

WHEkEAb, che Clanch Kiver MKS l'ask force has been jointly appointed by che koane luunty kixecutive and the Cicy Councll ot Uak kidgu to evaluate the Mks lacildty propused by but to be constructed in the koune County purtion of Uak kidgt, and

WHEKEAS, for deveral months the Clinch Kiver MRS Task Force has carefully evaluated the proposal and has arrived at a position on the Mks which identifies the communities' concerns, describes the potential iupacts of the proposed facility, and recommend mppropriate mitigative measures, and

WHEREAS, it is the position of the Clinch River MRS Taok force tbat, if DOE is required by Congress to comply with those stringent but reasonable mitigative measures, the proposed MRS could be safely built and operated and would constitute a beneficial addition to the region's economic base with no harmful effects ensuing.

NOW, THEKEFURE, BE IT KESOLVED BY THE MAYOK AND COUNCILMEN OF THE CITY OF OAK RIUGE, T'ENNESSLE:

Ihat the City loulcil of Oak kidge hereby adopts the position of the Clinch Rivur MKS Task force as its own and encourages che State of Tennessee, the Lepartment of tinergy, and the U.S. Congreas to support che incorpcration of the position into the Mks legislation and associaced ayreements.

HE IT FUKIHEK KESULVLU that with the compliance of the conditions set forth in the adophed position, the lity Council of Oak kidge would willingly accept location ot the proposed Mks facility within its jurisdicrional limits.

BE II FUK'THEk KLSCHED that the Clinch Kiver MkS lask force is hereby authorized to promote with state. and kederal-appointed officials full underatanding and consideration of the city's adopted position.

This the $21 \mathrm{st}$ day of October 1985.

APPROVED AS TO FOKM

AND LEGALITY:

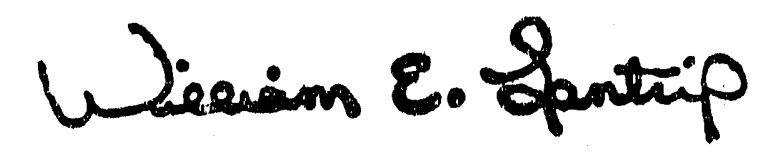

City Attorney

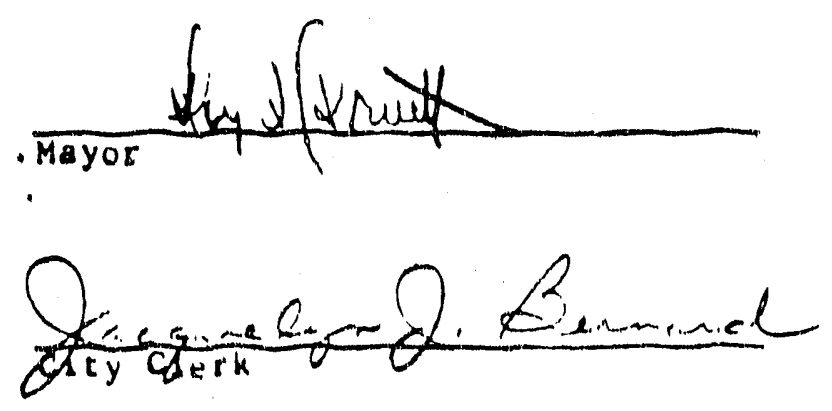




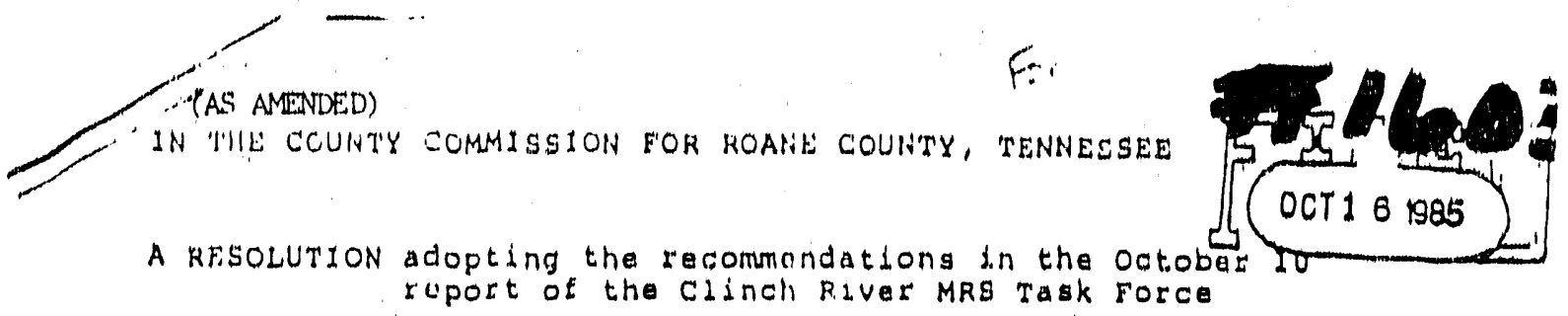

WIEREAS, the Clinch River MrS Task Force appointed by the Roans County Executive and the oak Ridge city Council has aubintitad a report to the governing bodies requesting the adoption of a var dea of recommendations.

NOW; THERLFORE, BE IT REMOLVED that the BOArd of Commissioners of Roans County, meeting in special session on october 22, 1985, does adopt the recommendations in the october 10 report of the clinch River MRS Task Force. Roan County thereby accepts the position that based on information to date, the MRS facility could be acceptable to Roane county and provide a net economic benefit to our citizens is conditions equivalent to those in the rask Force Report are securely actaflad by the authorizing leglolation and Intergovernmental agreements provided for by that legislation.

BE IT FURTHER RESOLVED that the state of Tennessee and the Tennessee Congressional Delegation axe asked to help obtain adoption of the requested conditions.

BE IT FURTHER RESOLVED that the state of Tennessee and The Department of Energy are thank ad for their strong cooperation with the Clinch River MRS Task Force.

Upon motion of Commissioner Langley, seconded by Commissioner Crews the following commissioners voted Aye: Crews, Delaney, Button, Ferguson, Hatfield, Hacker, Honeycutt, Houston, Langley, Money, Renfro. (11)

The following Comm is loners passed None

1 The following Commintoner voted No: None

Thereupon, the County Chairman announced to the Court that said resolution had received a constitutional majority and ordered same spread of record.

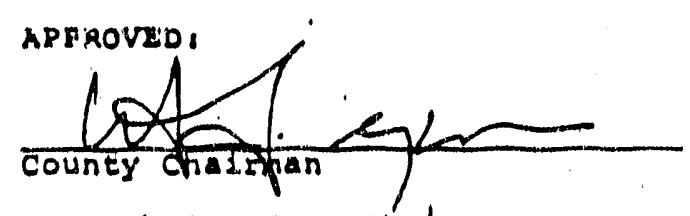

The foregoing resolution was submitted to tha/county Executive cor his consideration the $2-2$ day os 290.

ATTESTED:
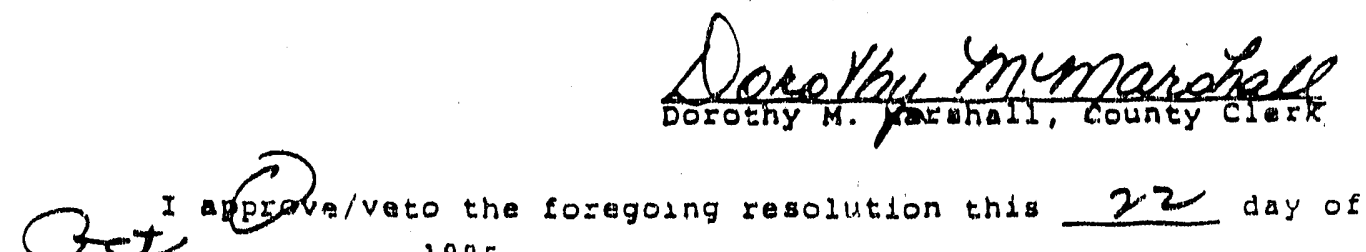
. 2905.

ATE OF TENNESSEE INT OF ROANS, lest: lofty M. Marshall

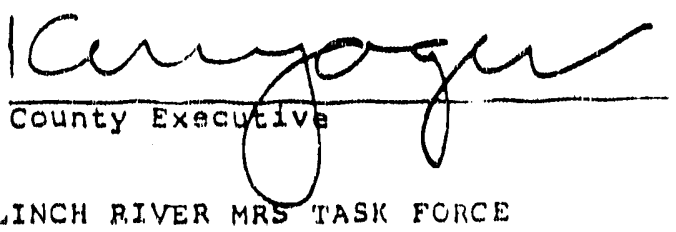

END DATE $6.8-92$. 